\title{
To the biology of celery fly Euleia beraclei (Linnaeus, 1758) (Diptera: Tephritidae) - pest of alien Apiaceae species in Moscow Region
}

\section{К биологии сельдерейной мухи Euleia beraclei (Linnaeus, 1758) (Diptera: Tephritidae) - вредителя чужеродных видов зонтичных растений в Московской области}

\author{
M.G. Krivosheina ${ }^{1}$, N.A. Ozerova ${ }^{2}$ \\ М.Г. Кривошеина ${ }^{1}$, Н.А. Озерова ${ }^{2}$
}

\begin{abstract}
${ }^{1}$ A.N. Severtsov Institute of Ecology and Evolution, Russian Academy of Sciences, Leninsky prospect 33, Moscow 119071, Russia. E-mail:kriv2260@rambler.ru

'Институт проблем экологии и эволюции им. А.Н.Северцова РАН, Ленинский проспект, 33, Москва 119071, Россия.

${ }^{2}$ S.I. Vavilov Institute for the history of science and technology, Russian Academy of Sciences, Staropansky lane 1/5, Moscow 109012, Russia. E-mail: ozerova-nad@yandex.ru

${ }^{2}$ Институт истории естествознания и техники им. С.И. Вавилова РАН, Старопанский переулок, 1/5, Москва 109012, Россия.
\end{abstract}

KEY WORDS: Diptera, Tephritidae, larva, pest, Euleia heraclei, biology, ecology, global warming, natural conditions, Heracleum sosnowskyi.

КЛЮЧЕВЫЕ СЛОВА: Diptera, Tephritidae, личинка, вредитель, Euleia heraclei, биология, экология, глобальное потепление, естественные условия, Heracleum sosnowskyi.

ABSTRACT. Biology of celery fly Euleia heraclei (Linnaeus, 1758) (Diptera, Tephritidae) was studied in Moscow Region. In spring larvae damage leaves of Apiaceae plants of the second - year vegetation, in the end of summer and in autumn - leaves of young plants. In spite of the increase of the duration of warm season the fly develops in 2 generations under natural conditions. Serious injury caused by celery larvae is registered according to grown seedlings of Heracleum sosnowskyi Mandenova in autumn.

РЕЗЮМЕ. Биология сельдерейной мухи Euleia heraclei (Linnaeus, 1758) была изучена в условиях Московской области. Весной личинки повреждают листья дикорастущих и культурных зонтичных растений двухлетнего возраста, в конце лета и осенью - листья годовалых растений. В природных условиях, несмотря на увеличение продолжительности теплого сезона, муха развивается только в 2 поколениях. Отмечен серьезный вред, наносимый личинками молодым растениям борщевика Cocновского осенью.

\section{Introduction}

The genus Euleia Walker 1835 units 11 valid species, distributed in Palaeacrtic, Nearctic and Oriental regions [Norrbom et al., 2012], palaearctic fauna being the richest and containing 7 species. The larvae of all species of the genus are supposed to be primary pests of live plant tissues [Ferrar, 1987]; the most being discussed are the two species: E. heraclei (Linnaeus, 1758), damaging wide spectrum of Apiaceae in Palaearctic region and E. fratria (Loew, 1862) with close biology, damaging Apiaceae and Compositae plants but distributed in Nearctic. Many investigations were fulfilled to prove the negative effects of these two species to cultural plants from the family Apiaceae [Keilin, Tate, 1943; Tauber, Toschi, 1965; Leroi, 1973; Korneyev, 1991; Carroll et al., 2006]. We decided to review the significance of one of these species, $E$. heraclei, from another angle - its role in damage of Apiaceae alien plants, particularly invasive Heracleum sosnowskyi Mandenova - species which aggressive spread caused many problems in different territories of Russia as well as in other countries of the world.

\section{Material and methods}

Experimental materials were collected in 2012-2016 years in Shakhovskoy District of Moscow Region during April-November. The next species of Apiaceae proved to be infested by the celery fly: Levisticum officinale Koch., Apium graveolens L., Pastinaca sativa L. (var. pratensis, var. sativa) and Heracleum sosnowskyi. Larvae of Euleia heraclei were observed on live plant as well as partly collected and reared under laboratory conditions. The time of development of each stage was recorded. Morphological studies were based on larvae, prepared by the following method: live larvae were treated with hot water about $90^{\circ} \mathrm{C}$, then kept in $70 \%$ alcohol. Larvae were preparated, cut along 
lateral side of the body and put in $30 \% \mathrm{KOH}$ for 10 hours till internal tissues dissolved. Then they were studied under microscope. The damage was evaluated by counting the broken area of the leaf and by registration of the number of survived seedlings next spring. The data on the distribution of the fly in Russia were summarized using specimens kept in Zoological Museum Moscow University and Zoological Institute, St.Petersburg.

\section{Euleia heraclei (Linnaeus, 1758)}

MATERIAL. 1 , "Ust Tsilma, Pechora uezd, Arkhangelsk gubernia", 14.VII.1905, Zhuravslkij; $1 \sigma^{7}$, "Alexandrovsk, Murman.[sk]", 24.VIII.1923, V. Kuznetsov; 2 +o, "Jukki, Distr. Petrograd", 5.VI.1931; 25.VI.1931, A.A. Stackelberg; 1 , "Petrograd gubernia, Taitzy", 30.V.1916, A.A. Stackelberg; 2 우, "Vic. Luga, NW Russia, Tolmatschevo", 28.V.1934; 23.VIII.1935, A.A Stackelberg; 5 ㅇ, "Yashera, Luzsk., Leningrad Obl.", 7.VI.1963; 6.VII.1963; 15.VIII.1968; 16.VIII.1968; 21.VIII. 1968, A.A. Stackelberg; 19, larvae, Moscow Region, Shakhovskoy District, Burtzevo, on Levisticum officinale, 23.VI.2013; 1 \% larvae, the same place, on Pastinaca sativa, 23.IX.2012; 28.IX.2012; larvae, the same place, on Heracleum sosnowskyi, 15.VIII.2014, 20.XI.2012; larvae, the same place, on Apium graveolens, 25.IX.2014, M.G. Krivosheina; 1 , Serpukhov, 29.V.1903, B.K. Gindtse; 1 , "Serpukhovskoy uezd", 12.VIII.1902, O. Sherbina; 2 우, "on Levisticum officinale, Crimea, Nikitskiy Botanicheskiy sad", 11.VI. 1931, 1.VII.1929, E. Kozlova; 1 , "Verhne Inbatskoe, downstream of Yenisei river", 29.VI.1905, Anuchina; 1 9 , "Irkutsk", without date, V. Yakovlev; $10^{7}$,"Yuzhno-Sakhalinsk", 19.06.1954, N. Violovitch; 1 ․, "Kuril Islands, near lake Lagunnoe, Kunashir", 30.VI.1968, E.P. Nartschuk; $1 \sigma^{7}$, "Kuril Islands, Kunashir, Sernovodsk", 30.VI.1968, E.P. Nartschuk; $10^{7}, 1$ †, "Urup, Kompaneyskiy", 7.07.1954, N.A. Violovitch.

LIFE-HISTORY. In Moscow Region the celery fly appears in spring in the end of April - beginning of May. Imagoes are distinctly determined for they have patterned wings of typical structure (Fig. 1). In 3-5 days adults are ready to copulate and oviposite. Flies look for Apiaceae plants and lay eggs by one inside leaf tissue. Larva emerges in 7-9 days, larval development requires 14-18 days. Stage of pupa lasts for about 1.5-2 weeks, males emerge 2-3 days earlier, than females. Adult longevity is no less than 4 weeks. So minimal time for the life-cycle is 5 weeks if the weather is warm and stable. Larvae of the second generation are registered in the middle of August - the middle of October. Presumably the fly overwinters at pupal stage, but several imagoes were noticed to emerge in November.

DAMAGE. Larvae hatch and start grazing leaf tissue, forming a blotch visible from outside owing to another coloration of damaged tissue and empty cavities inside leaf. There may be 2-3 larvae inside one common mine. Larva is very active and may be distinguished by almost constantly moving back and forth cephalopharyngeal skeleton noticeable across thin cover of the gallery and transparent integument of larva. Pupation usually occurs in soil, very rarely - inside drying leaf in laboratory. The first generation of the celery fly uses Apiaceae of the second-year age, large leaves of which appear in early spring. Females lay eggs on the lower surface of the leaf inside cavities made with the help of ovipositor; the stimulation of the process is fulfilled after the contact of the fly with young fresh leaf [Leroi, 1973]. The same author reported about the migration of a part of larvae to another leaf and making there the secondary mine. He explained this phenomenon by insufficient amount of food for several larvae in one leaf or as a result of fungal infection of plant tissues. We observed regularly 2-3 larvae inside large fused mine but never free larva moving along the leaf surface. Each female can lay to 100 eggs [Hill, 1987]. Imagoes of the first generation emerge in the second-third decades of June. It seems that in nature the second oviposition happens in August, so imagoes may live at least 2 months. Larvae were not registered in the end of June-July, so we suppose 2 generations in Moscow region only. As the most probable purpose of such phenomena different authors noted the requirement of some certain age of growing leaf [Richter, 1981]. Larvae of the second generation develop in plants of the first-year age in autumn when the leaves are rather large.

HARMFULNESS TOWARDS ALIEN SPECIES. In reference to Heracleum sosnowskyi the next regularity was registered: the flies of the first generation never laid eggs on the hog-weed leaves in spring; those mines which are evident on the leaves of Heracleum belong to Epermenia chaerophylella (Goeze, 1783) and Phytomyza pastinacae Hendel, 1923 [Krivosheina, 2009, 2011]. Grown-up seedlings are attacked by this fly in the end of summer and autumn (AugustOctober). For the size of leaves are rather small at this time (as a rule from 5 to $8 \mathrm{~cm}^{2}$ ) the mine with damaged by 1 larva area of $2-3 \mathrm{~cm}^{2}$ (totally from $1 / 4$ to $3 / 5$ of leaf surface) on almost each or at least every second leaf and the presence of 2-3 larvae inside one leaf cause serious degradation of the plant. As a result from 80 to $95 \%$ seedlings perished due to such attack on the plot of mass development of the fly. Of course we are to realize that Euleia heraclei can not be used in some way in biological control of the giant hog-weed like other insects [Reznik et al., 2008; Krivosheina, Ozerova, 2014], for it damages cultural crops also; however such phenomen is to be considered during evaluation of Heracleum effect on biocenosis. Pastinaca sativa L. has another pattern of interaction with the pest. Flies attack the leaves of this plant in early spring. The damage of the leaves in our case was distinctly registered, the mines had the dimension of $1.8-2.2 \mathrm{~cm}^{2}$. Dying of part of leaves happened, but the plants did not demonstrate severe depression and produced enough normal seeds in summer. The same situation was observed for Levisticum officinale.

MORPHOLOGICAL DESCRIPTION. Larva (Figs 2 , 4-10). Body length 7-8 mm, body width $1.5-1.8$ $\mathrm{mm}$. Creamy-white, broader posteriorly and tapered anteriorly, with translucent dark cephalopharyngeal skeleton. Oral ridge with 8 dents at each side (Fig. 4); atrium weakly developed. Antenna simple, one-segmented. Maxillary palpus round, with 6-9 small pointed papillae. Cephalopharyngeal skeleton sclerotized incompletely. Mandibles massive, short, each with 3 

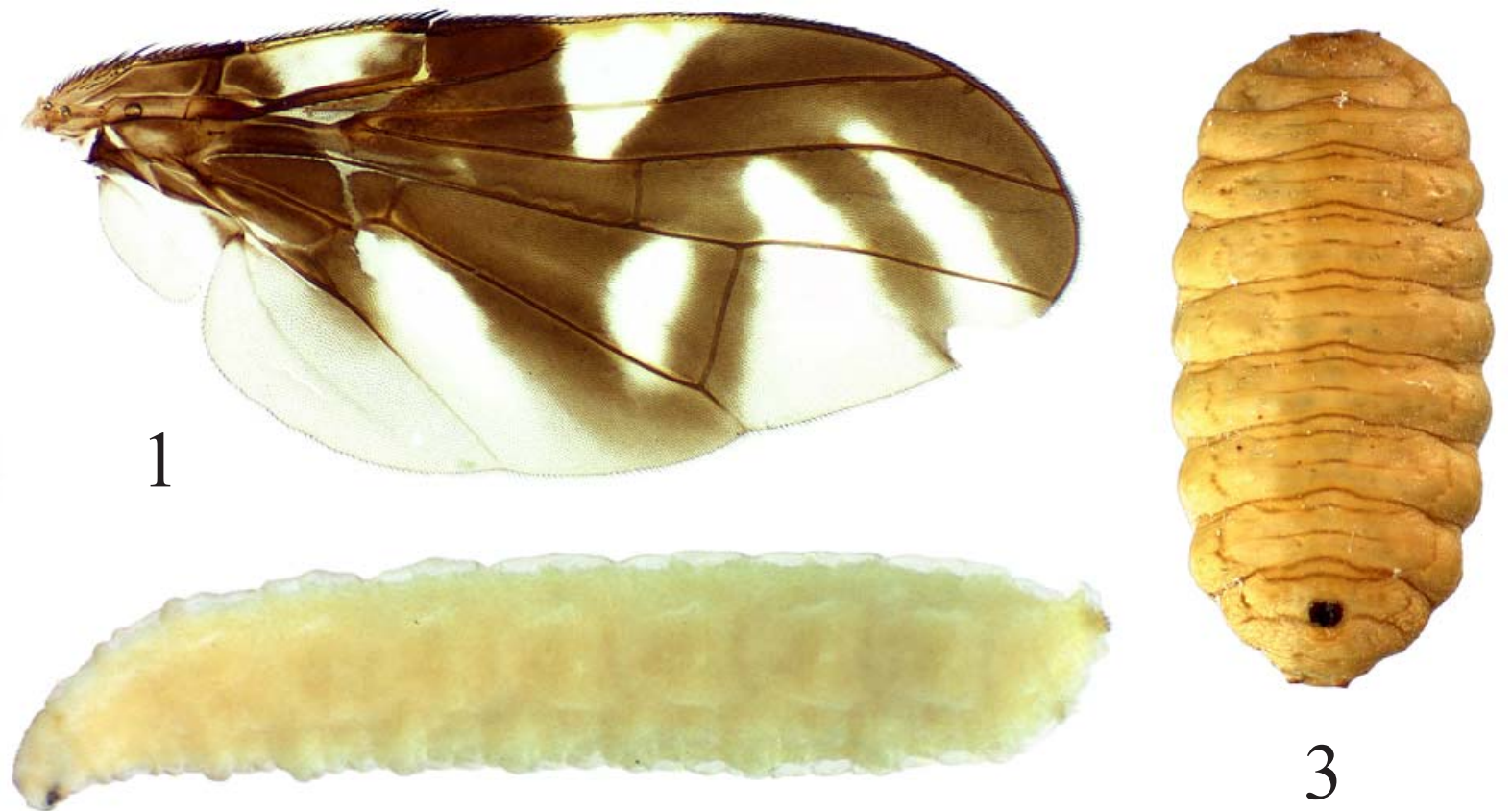

2
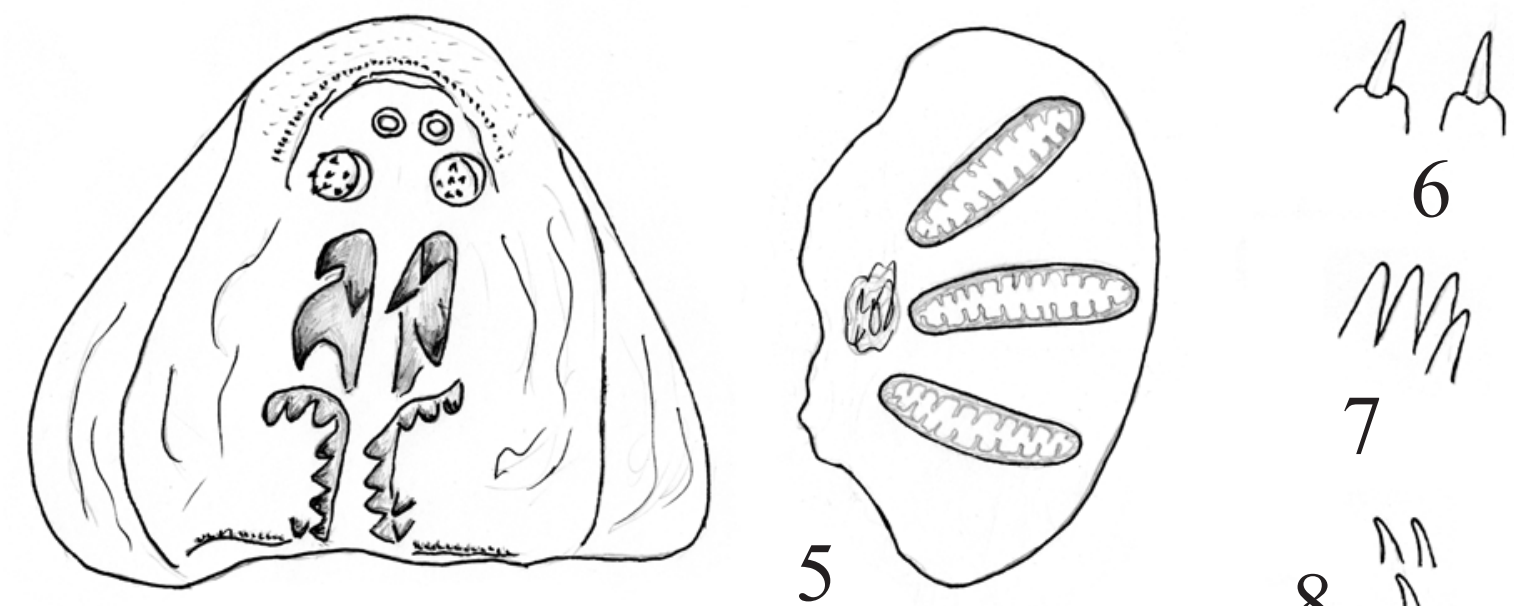

6

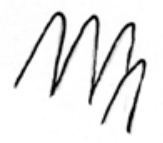

7
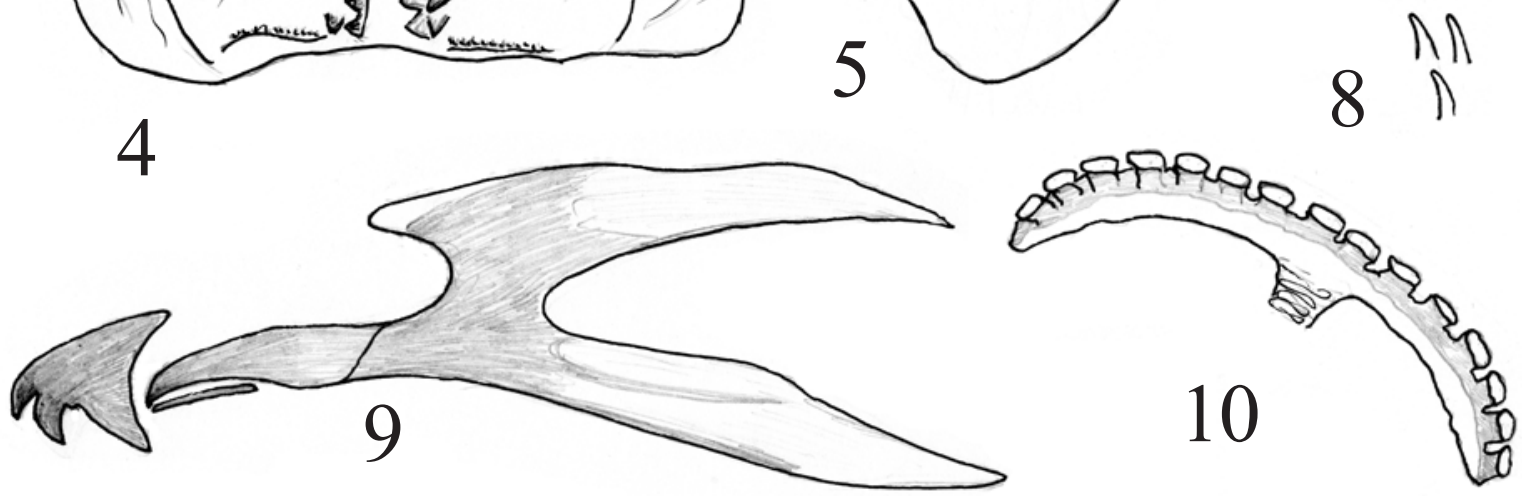

Figs 1-10. Detailes of morphology of imaginal and immature stages of Euleia heraclei (Linnaeus, 1758): 1 — wing; 2 - larva, lateral view; 3 - puparium, ventral view; 4 - head, ventral view; 5 - posterior spiracle, dorsal view; 6 - spines of thoracic segments; $7-$ group of spines on ultimate body segment; 8 - spinules of ultimate body segment; 9 - cepalopharyngeal sceleton; $10-$ anterior spiracle.

Рис. 1-10. Детали строения имаго и преимагинальных стадий Euleia heraclei (Linnaeus, 1758): 1 - крыло; 2 - личинка, общий вид сбоку; 3 - пупарий, вид снизу; 4 - головной отдел личинки, снизу; 5 - заднее дыхальце, сверху; 6 - шипики грудных сегментов тела; 7 - группа шипиков на последнем сегменте тела; 8 - одиночные шипики последнего сегмента тела; 9 - ротоглоточный скелет; 10 - переднее дыхальце. 


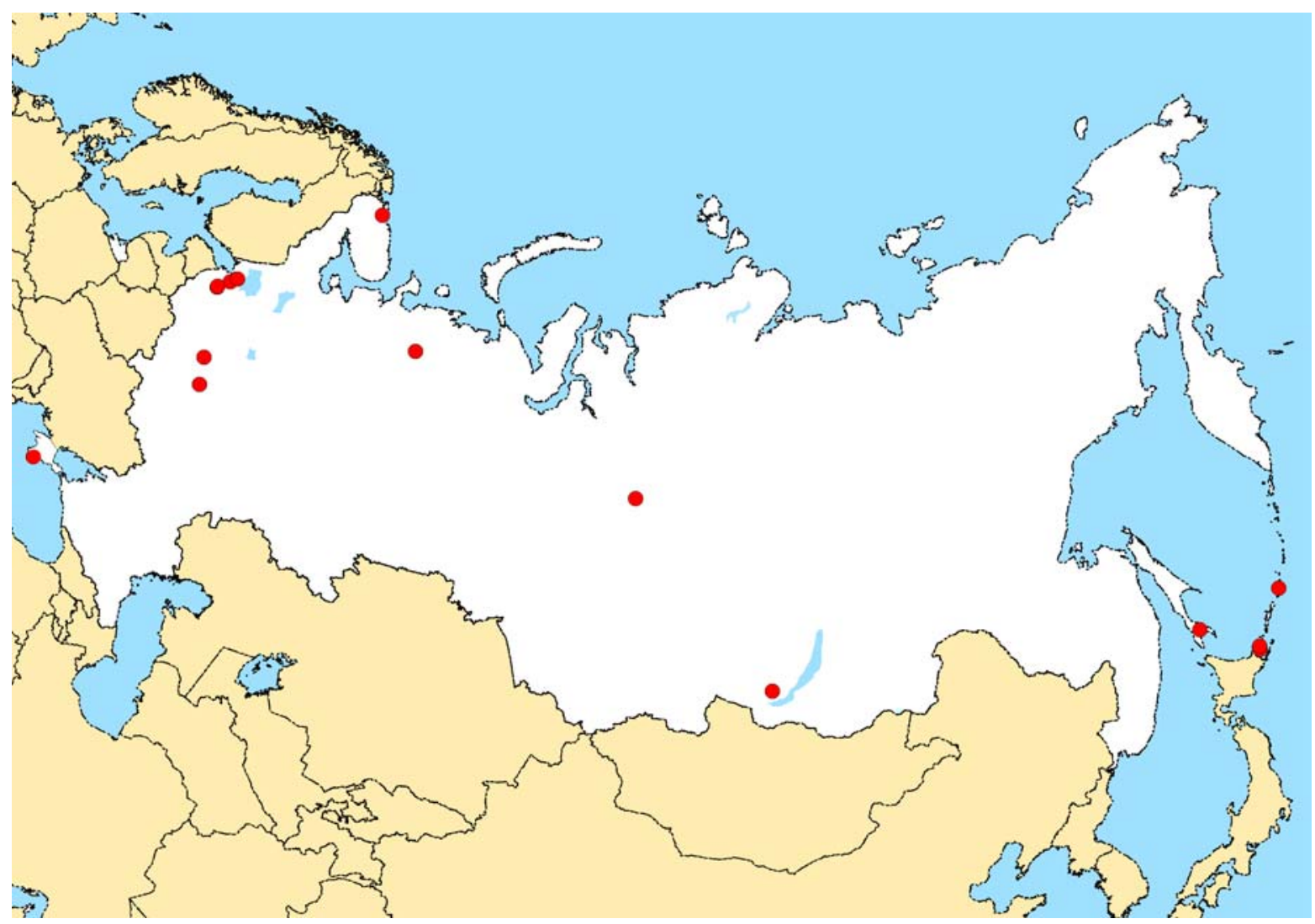

Fig. 11. Map of distribution of Euleia heraclei (Linnaeus, 1758) in Russia.

Рис. 11. Карта распространения Euleia heraclei (Linnaeus, 1758) в России.

large dents (Fig. 4). Hypostomal sclerites long and sclerotized, pharyngeal sclerite with dorsal and ventral cornua anteriorly sclerotized, dorsal cornua shorter, than the ventral (Fig. 9). Anterior spiracle with small spriracular chamber, a little curved and adjoined to integument, with 15-16 spiracular openings situated in more or less regular row (Fig. 10). Thoracic segments with indistinct rows of transparent conical spines (Fig. 6). The other segments seem to be without such spines, for the rows are irregular and interrupted. Ultimate body segment with 2 types of structures: groups of large transparent elongate spines and irregular rows of small spinules (Figs 7, 8). Posterior spiracles are separate, little projecting beyond the surface, distance between them like 2-width or spiracular plate. Each spiracle with 3 spiracular openins arranged radially (Fig. 5). Spiracular hairs organized in 4 groups and poorly developed. Anal plate dark, transverse, about 2 times as wide as long, with 6 marginal dents at each side.

Puparium (Fig. 3). Body length $5 \mathrm{~mm}$, body width $2 \mathrm{~mm}$. Creamy-white or a little greenish, compact, segmented, with transverse folds. Anterior spiracles and anal plate brown.

DISTRIBUTION. Some time ago E. hearclei was reported to be distributed in North America as well as in Europe [Hill, 1987: map]. In following publications [Carrol et al., 2004; De Jong et al., 2014; Pitkin et al., 2016] the distribution of the fly in Europe was pre- cised: E. fratria was proved to occur throughout United States of America and E. heraclei — in Europe only. Up to the present the distribution of the fly is cofirmed for Finland, France, Germany, Greece, Hungary, Ireland, Italy (Sardinia, Sicilia), Kazakhstan, Lithuania, Malta, Moldova, Northern Aegean Islands, Norway, Poland, Russia, Slovakia, Spain, Sweden, Switzerland, Netherlands, Ukraine. Besides, it was told, that the fly was registered in East Palaearctic (Japan). The latest registrations happened in Cyprus and Serbia [www.diptera.info]. The fly is known from the Near East: Arabian peninsula, Armenia, Azerbaijan, Caucasian Russian Republics, Egypt, Georgia, Iraq, Iran, Israel, Jordan, Lebanon, Syria, Tadjikistan, Turkey [Korneyev, 1991; Norrbom et al., 2012; De Jong et al., 2014].

Such very wide distribution of the fly is possibly the result of the development in many Apiaceae species, including cultural ones. However the species proved to be rather rare in insect collections; this happened possibly because imagoes lived inside tree crones where they fed on honey-fall and nectar [Richter, 1981] and were not captured with standard methods. Many of specimens presented in collections were rared from larvae. V. Korneyev [1991] in his revision of the genus Euleia reported about few specimens from Russia only: 2 males from Sahkalin and 1 male from Kuril Islands. 
The study of collection materials of the Zoological Museum, Moscow University and Zoological Institute, St.-Petersburg allowed us to expand our knowledge about the area of E. heraclei (Fig. 11).

NOTES. The life cycle of Euleia heraclei, according to our observations, lasts 5-6 weeks. The expansion of "warm period" from early April till late November which we see during the latest years allowed us to suppose and try to check whether the third generation is possible in Moscow Region. Such assumption was based on the fact, that some authors reported about 2-3 generations for this species [Hill, 1987] and the close species, E. fratria, demonstrated 3 generations in the laboratory. The opinion of many authors that females need leaves of certain stage of maturation resulted in our attempt to offer leaves of another "age" to the flies and observe the results. So, we created several plots with celery and cow parsnip crops of different age inside the site with mass reproduction of this fly in June-July. No leaves damaged by E. heraclei were observed.

RESULTS. There are 2 generations of celery fly, $E$. heraclei in Moscow region. In spring the flies attacked second-year plants of P. sativa, L. officinale and A. graveolens. Larvae reached the third instar and pupated on the 10-13 of June in P. sativa and A. graveolens and on the $23-25$ of June - in L. officinale. The damaged surface of leaves varied from 5 to $10 \%$; in each case no significant harmful influence on the plant or on its seed production was noticed. The second generation of larvae started their development from the middle of August and were observed on leaves of firstyear plants of Pastinaca, Apium and H. sosnowskyi. Larvae settled also Pastinaca and Apium planted in early spring and flowering in September-October. The damage of the second generation was much more serious, about 30 to $70 \%$ of leaves were eliminated.

ACKNOWLEDGEMENTS. The work was realized with financial support of Russian Science Foundation, Project No 16-14-10323 "The biological invasion of alien species of organisms in the terrestrial and aquatic ecosystems under conditions of global climatic and anthropogenic impacts".

\section{References}

Carroll L.E., Norrbom A.L., Dallwitz M.J., Thompson F.C. 2004 Pest fruit flies of the world - larvae. Version: 8th December 2006. http://delta-intkey.com/, accessed on 22 April 2016.
De Jong Y. et al. 2014. Fauna Europaea - all European animal species on the web // Biodiversity Data Journal. Vol.2. No.e4034. http://www.faunaeur.org/, accessed on 22 April 2016.

Ferrar P. 1987. A quide to the breeding habits and immature stages of Diptera Cyclorrhapha // Entomonograph. Vol.8. Pt.1-2. $895 \mathrm{p}$.

Hill D.S. 1987. Agricultural Insect pests of temperate regions and their control. Cambridge: Cambridge University Press. 659 p.

Keilin D., Tate P. 1943. The larval stages of the celery fly (Acidia heraclei L.) and of the braconid Adelura apii (Curtis) with notes upon an associated parasitic yeast-like fungus // Parasitology. Vol.35. No.1. P.27-36.

Korneyev V.A. 1991. [Tephritid flies of the Genera Allied to Euleia (Diptera, Tephritidae) in the USSR. Communication 2] // Vestnik zoologii. No.4. P.30-37 [in Russian].

Krivosheina M.G. 2009. [Insects (Insecta), associated with Heracleum Sosnowskyi Manden in Moscow region and their role in ecosystems] // Byulletin' Moskovskogo Obshchestva Ispytatelei Prirody. Otdel Biologicheskiy. Vol.114. No.1. P.26-29 [in Russian].

Krivosheina M.G. 2011. Insect pests of Sosnowskyi hogweed (Heracleum Sosnowskyi) in Moscow region and the prospects of their usage in biological control // Russian Journal of Biological Invasions. Vol.2. No.2-3. P.99-106.

Krivosheina M.G., Ozerova N.A. 2014. A method for ravage of Heracleum Sosnowskyi. Patent for contrivance RUS 2556068, 10.04.2014. 9 pp.

Leroi C.R. 1973. A study of natural populations of the celery leafminer, Philophylla heraclei L. (Diptera, Tephritidae) II. Importance of changes of mines for larval populations // Researches on Population Ecology. Vol.15. No.1. P.163-182.

Norrbom A.L., Carroll L.E., Thompson F.C., White I.M., Freidberg A. 2012. Euleia Walker, 1835. Systema Dipterorum, Version 1.5. 1 record. http://www.diptera.org/, accessed on 22 April 2016.

Pitkin D., Ellis W., Plant C., Edmunds R. 2016. The leaf and stem mines of British flies and other insects. Version: 13th February 2016. http://www.ukflymines.co.uk/index.php/, accessed on 22 April 2016.

Reznik S.Ya., Dolgovskaya M.Yu., Zaitzev V.F., David'yan G.E., Nentvig V.O. 2008. [The possibility of use of weevil Nastus fausti Reitter (Coleoptera, Curculionidae, Entiminae, Nastini) for biological monitoring of invasive species of the hogweeds (Heracleum spp.)] // Entomologicheskoe Obozrenie. Vol.87. No.3. P.487-502 [in Russian].

Richter V.A. 1981. [Family Tephritidae] // Nartschuk E.P., Gorodkov K.B. (eds.). Insects and mites - pests of agricultural crops. Vol. IV. Hymenoptera and Diptera. Leningrad: Nauka. P.106-140 [in Russian].

Tauber M.J., Toschi C.A. 1965. Bionomics of Euleia fratria (Loew) (Diptera: Tephritidae): 1. Life history and mating behaviour // Canadian Journal of Zoology. Vol.43. No.2. P.369-379. 